\title{
実場面における滞留と移動の環境行動に関する考察 \\ STUDIES ON THE ENVIRONMENTAL BEHAVIOR OF THE ACTUAL SITUATION AROUND MOVING AND STAYING
}

\author{
田中元 喜*, 竹内友里**, 西澤志信**, 山下哲 郎*** \\ Motoki TANAKA, Yuri TAKEUCHI, Shinobu NISHIZAWA \\ and Tetsuro YAMASHITA
}

\begin{abstract}
In this study, we aim to clarify the charactaristics of environmental behavior around moving and staying by field surveys, and examined from the two points of view of relations between humans and their surounded physical environment.

The results of the investigation were summarized as follows,

1) If the density in the space became larger, the territories of moving and staying become acquainted and vague.

2)Environmental behavior is affected by the properties of physical environment.

3)Personal space is bigger than it by past experimental studies. And so, environmental behavior have various interrelations.
\end{abstract}

Keywords : personal space, environmental behavior, moving, staying, concourse of station パーソナルスペース, 駅コンコース, 環境行動, 移動者, 滞留者

1.はじめに

\section{1-1. 研究の背景と目的}

人間は他人との距離を調整することで適正な関係を維持しているこ とがホールの個体距離研究やソマーのパーソナルスペース論により指 摘されており、「個人の空間には侵入者が入れないようにその人を取 り囲む見えない境界を持った領域が存在する」辣 1 と理解されてきた。 パーソナルスペースの概念は建築分野において、高橋らの一連の研 究部 2 にって、位置関係だけでなく体の向きを扱うことによって、2 次元的な空間として説明され、建築空間の構成を人間行動の特性から 説明しようと試みられた。続けてこれらの特性は更に 3 次元的に拡大 されようとしているが、それらの研究は実験によるものや、場所の限 られた部分 (場面) を観察するものが多く、移動者/滞留者を含め 様々な人が交錯し多様な物理的環境が存在する面的に広がる実際の場 所には及んでいなかった。

一方で密度の側面からは、安全に効率よく人が行動するための研究 が、避難・交通分野において行われてきた。それらは、如何に人間が 障害物を避けるかということを説明し、大量の人の行動に着目した群 集流動や個人の快適性を求めるものまである。しかし逆にこれらは人 と環境の関係を固定的なものとして捉え、種々の状況に応じた相互関
係として言及しようとするものではない。

建築空間は、最低限の生理的合理性や効率を満足するだけでなく、 より日常生活に即した人間性を尊重した空間づくりが求められ、それ にふさわしい計画が必要とされる。具体的には、人と人あるいは人と 物理的環境の相互関係の中で、しかも、ある広さをもった害際の空間 で環境行動を捉えることが、次なる課題と考え、本研究では、フィー ルド調査において、人の移動／滞留という環境行動的特性袨3を得るこ とを目的とした。

\section{1-2. 研究の概要}

本研究では、写真により場面を捉え、移動者と滞留者の各々の特性 を対物環境 (人とものの関係) と対人環境 (人と人の関係) の側面か ら考察した。次にこれを補完するためにビデオ撮影により、時間軸の 中で人の行動を追い人と人の相互関係について捉え考察した。

こうした移動/滞留の様態を種々観察収録し得る場所の典型事例と して、駅コンコースが考えられるか、研究の目的に照らしてある程度 の密度を必要とすることから、名古屋市の金山駅コンコースとその駅

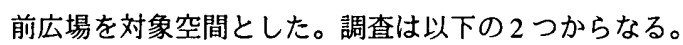

<調查 1 >調查員 24 人を図 1 に示す 1 2 24 の地点に配置し、各々 200 万画素以上のデジタルカメラを用いて、全調査員が同時刻にシャッ
* (侏)電通 修士 (環境学)

** 名古屋大学大学院環境学研究科 大学院生

**** 名古屋大学工学部 助教授・博士 (工学)
Dentsu Inc., M. Environment

Graduate Student, Graduate School of Environment Studies, Nagoya Univ.

Assoc. Prof., School of Engineering, Nagoya Univ., Dr. Eng. 
タ一を切ることによって、コンコースにおける人の行動の様子を撮影 した。調查日時は 2002 年 9 月 20 日（日の入り時刻 17 時 53 分、気温 $25.4^{\circ} \mathrm{C}$ 、天候 快晴) で、移動者と滞留者の両者が多く見られる夕方 17 時 15 分から 18 時 00 分の間に 6 回撮影した。本稿の分析において は、その中で最も欠損の少ない 17 時 55 分 00 秒を採用した。

<調査2>図1に示すA地区において 2 階店舗からビデオ撮影を行っ た。調查日時は 11 月 25 日（気温 $11.6^{\circ} \mathrm{C} 、$ 天候 小雨）で、7時 00 分から 9 時 00 分まで行い、自由に動くことができる場と制限を受け る場が混在する、人の適当な込み合い鼓 4 がみられる 8 時 30 分 00 秒か ら 24 秒までのデータを採用した。

\section{1-3. 調査データの概要 (表 1)}

金山駅コンコース部分の屋根の有無・天井高・幅員により、屋外部 分をく広場〉、屋内の北側の幅 $11 \mathrm{~m}$ 以下の部分をく通路〉、〈通路 >以外の屋内をくコンコース〉とする3つの場所に分類し分析してい く。調查では、この全ての場所において、調㚗対象面積の7割超を画 像で収録することができた。

また、写真から金山駅コンコース利用者を移動者、滞留者、移動／ 滞留が判別不能な人に識別した聙ところ、く広場〉は移動者数と滞留 者数に差がなく、くコンコース〉よりもく通路〉の方が移動者の占め

\begin{tabular}{|c|c|c|c|c|c|}
\hline & $=0$ & 広場 & コンコース & 通路 & 計 \\
\hline \multirow{4}{*}{$\begin{array}{l}\text { 利用者数 } \\
\text { (人) }\end{array}$} & 移動者数 & 49 & 177 & 51 & 277 \\
\hline & 滞留者数 & 49 & 108 & 15 & 172 \\
\hline & 判別不能者数 & 1 & 24 & 1 & 26 \\
\hline & 計 & 99 & 309 & 67 & 475 \\
\hline \multicolumn{2}{|c|}{ 調查面楥 $\left(m^{2}\right)$} & $2845(81)$ & $1836(80)$ & $237(73)$ & $4918(80)$ \\
\hline \multicolumn{2}{|c|}{ 実面築 $\left(\mathrm{m}^{2}\right)$} & 3496 & 2298 & 326 & 6120 \\
\hline \multicolumn{2}{|c|}{ 空間モテュール $\left(m^{2} / \lambda\right)$} & 28.7 & 5.9 & 3.5 & 10.4 \\
\hline
\end{tabular}
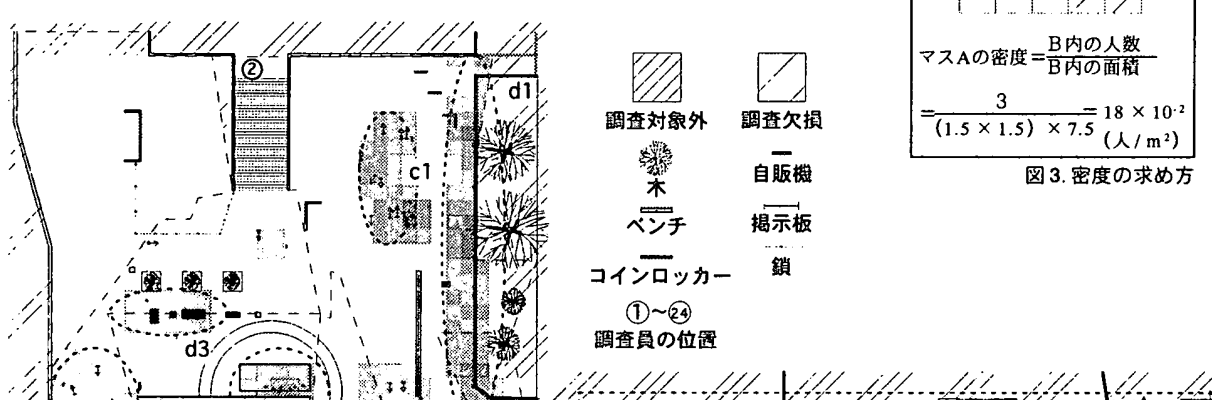

ペチ 揭示板

コインロッカー 瑀

(1) (24)

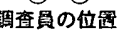

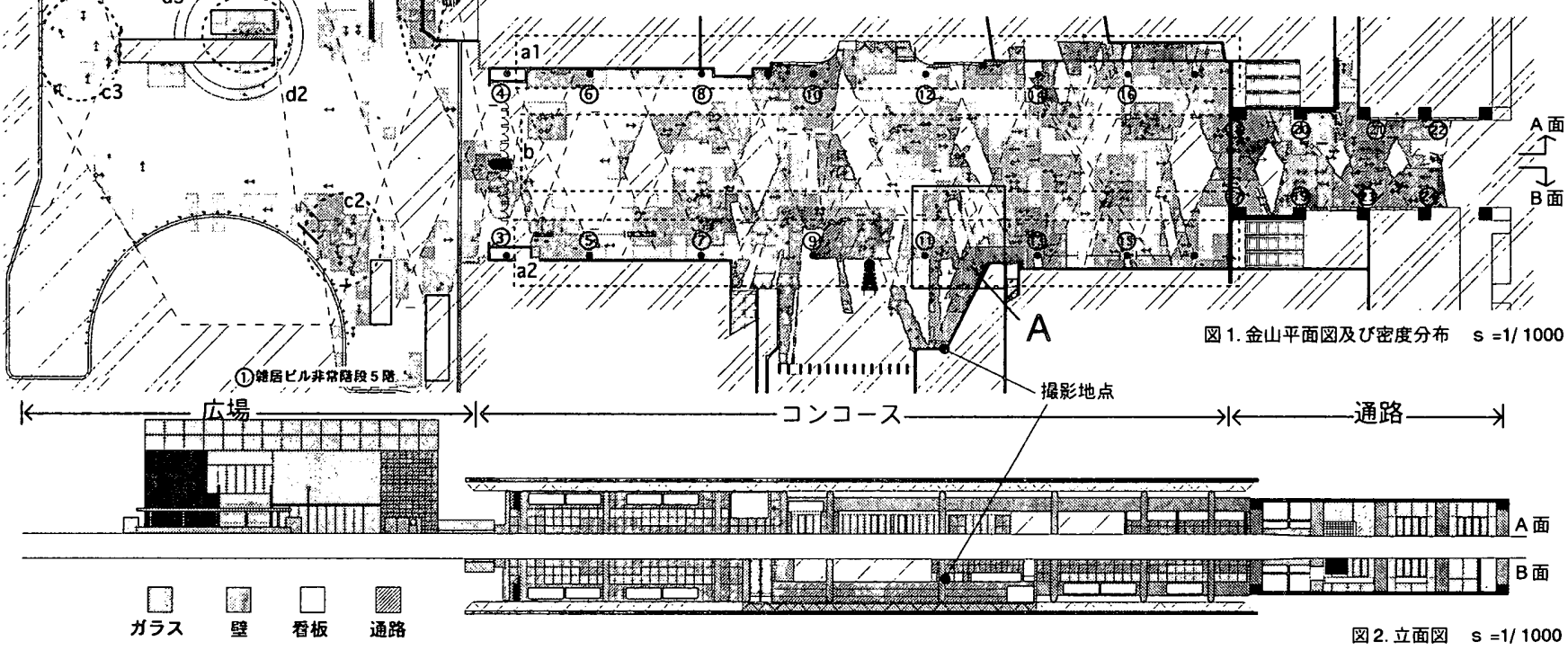

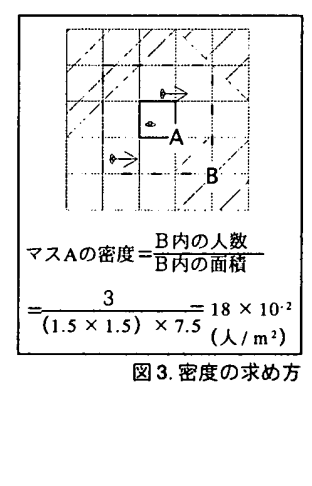

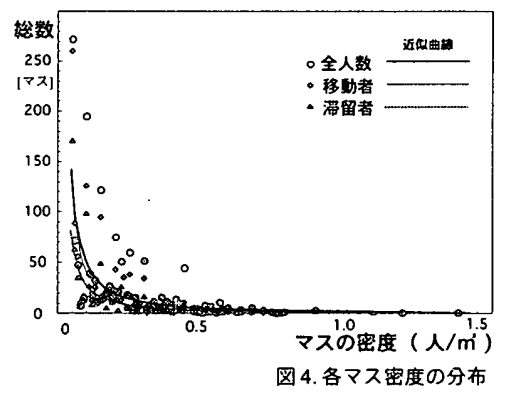

る割合が高くなっている。各場所の空間モデュールは、く通路〉が最 も大きくくコンコース $><$ 広場 $>$ の順に小さくなる赫。

\section{2. 調查対象空間の特性}

2-1.空間の広さや場の性格の違いによって移動者と滞留者の位置の違 いが生し、これが人の密度として現れると思われるので、本調查対象 空間の調查時点での特性を把握するため、人の分布の様子を密度の側 面から分析する。金山駅コンコースの特殊性であるが、床面が $15 \mathrm{~cm}$ $\times 15 \mathrm{~cm}$ のタイル張りになっており、そのメッシュを利用して、人の 右足位置を測定し、人の「位置」としている。本稿における密度は、 単位面積当たりの人数として算出する(図3)。具体的には、平面図に $1.5 \mathrm{~m} \times 1.5 \mathrm{~m}$ のグリッドを引き、1 マスことの密度で表現する。こ れは、15 c mの目地が全体に引かれているので、その夕イル目地 10 $\times 10$ を一つの単位としたからである。次にマスA $(1.5 \mathrm{~m} \times 1.5 \mathrm{~m})$ を 取り囲むマス 9 個 (範囲 B) の範囲の移動平均を求めるという手順で ある（但し欠損部分は除く）。

得られた各マスの分布（図4) は級数的であることがわかる。そこ で本稿においては、密度の違いがわかりやすいようにべき級数 $(2 \times)$ による密度分布をひとつの単位として、色分けして図 5 に表現した。 密度（図 1) は<広場 $>$ が最も高く、順にくコンコース ><通路 $>$ くコンコース〉にはストリートファニチュアや壁の近く（a1,a2地区） とそれらから離れた中央部分 (b 地区) に密度が高く、その間は比較 的低い。<広場＞は高密度の場所 (c1-c3,d1-d3) が点在しているが、

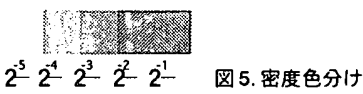
へと低くなっている。く通路〉は密度が全体的に高く、それに比へて 
人が居ない場所が多く存在する。

2-2. 移動者だけについて場所別に密度（図6）を見ていくと、くコ ンコース>においては、密度が高いのは中央部分 ( $\mathrm{b}$ 地区)のみで、ま たく広場〉は、密度が高いところは中央部分 $(c 1-c 3)$ のみに点在し ている。

滞留者について密度（図 7) を見ると、くコンコース ><広場 $>$ の 全ての場所において壁やストリートファニチュアの付近 (a1,a2,b1,b2) に密度が高くなっている。<通路〉も割合は低いが同 様の傾向を示した。

移動者と滞留者のそれそれれの密度分布を場所別に比較して見ると、

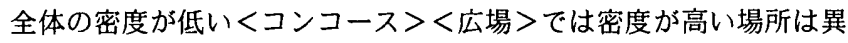
なっており、滞留者の居る領域と移動者が居る領域は離れる傾向があ ることがわかる。さらにくコンコース〉に比べるとく広場〉は、その 差がはっきりしている。またく通路〉のように移動者が空間の大部分 を占め、その密度が高い空間では、逆に滞留者の密度が低くなる傾向 があることがわかる。

\section{3. 人ともの（物理的環境）の関係}

3-1.移動者と滞留者を分け、各々の人から最も近い物理的環境への距 離と角度を測る。それそれれ総数は表 2 のようになり、ここでは表中 の主要な物理的環境との関係を考察する。

3-2.入口は移動者が通る場所であるため移動者との距離が小さいが、 一般に入口を除く全ての項目で移動者は、漁留者よりも物理的要素か ら離れた場所に位置することがわかる(図 8)。

3-3. 図9のように物理的環境を中心としたときの人の向きを分析す る。全体をみると、人は物理的環境を背にして滞留することが多く、 特に壁はその傾向が顕著である（図 10、表3)。それに対して揭示板 には向かい合うことが多い。当然掲示物を見ているからと考えられる が、仮に後ろを向く場合でも、壁と比較して、より遠くに滞留してい る。ガラスは視線を通す性質が影響しているためか、ガラスに向く傾 向も少なくない。丸柱においては、壁と同様、これを背にする場合が 多いか、向きは様々である。これは、丸柱も滞留者の居場所を固定す るのに有効であるが、一方で壁とは異なり多様な向きで居られること を示している。

\section{4. 人と人の関係}

4-1.図11のように対人距離を、ある人から最も近い人までの距離と 角度で求め、全ての対象者についてマス密度 1 5 別に近接対人距離 （図12）を見ていく。

密度が高くなるとともに平均距離は小さくなり、さらにその形は前 後 $\left(0^{\circ} / 180^{\circ}\right)$ に対して、左右 $\left(90^{\circ} / 270^{\circ}\right)$ の距離が小さくなる 傾向が読みとれる。つまり角度と距離において偏りが見られる。

また対人距離の分布の中心部分に空白ができている。人が自分の周 り（不快と感じる領域）に他人が入りこまないように、速度を変えた り向きを変えたりして距離調節をしていると仮定した場合、この空白 部分が、周囲の人の向きに関わらず、中心にいる人にとってのいわば パーソナルスペースに類似した領域とも考えられる。そこで移動者と 滞留者の別に、この領域を角度と距離の分布から以下で考察する。 4-2. 図13の4タイプのすへてて場合において、前後に比へ左右が小 さい形になっている。しかしそれそれ大きさは異なっており、同一行

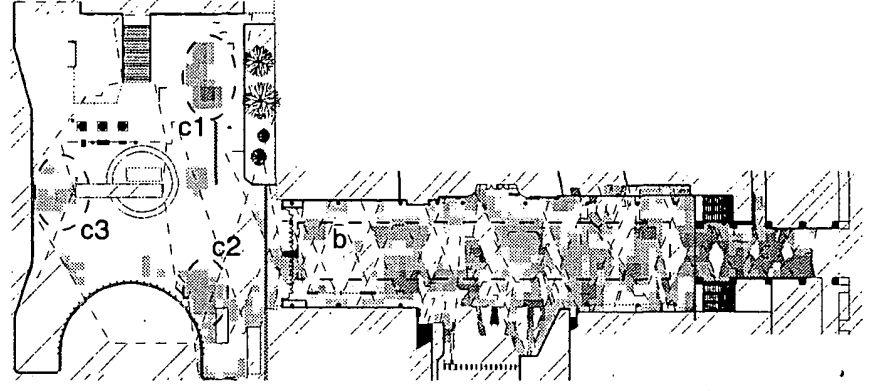

図6. 移動者密度 $s=1 / 2000$

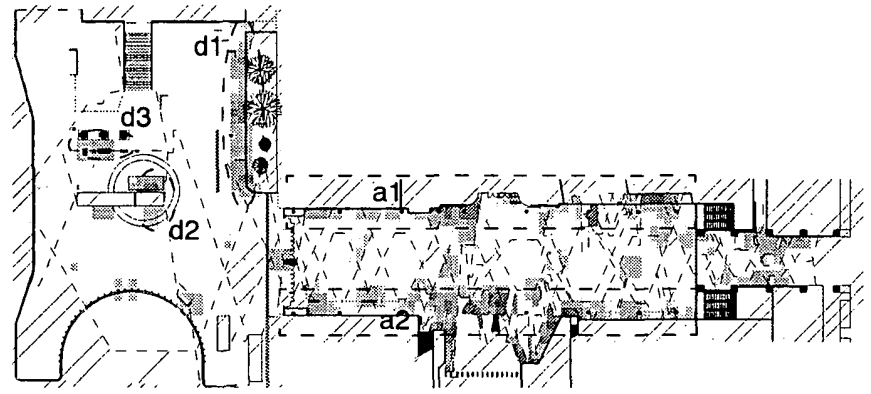

図7. 滞留者密度 $s=1 / 2000$
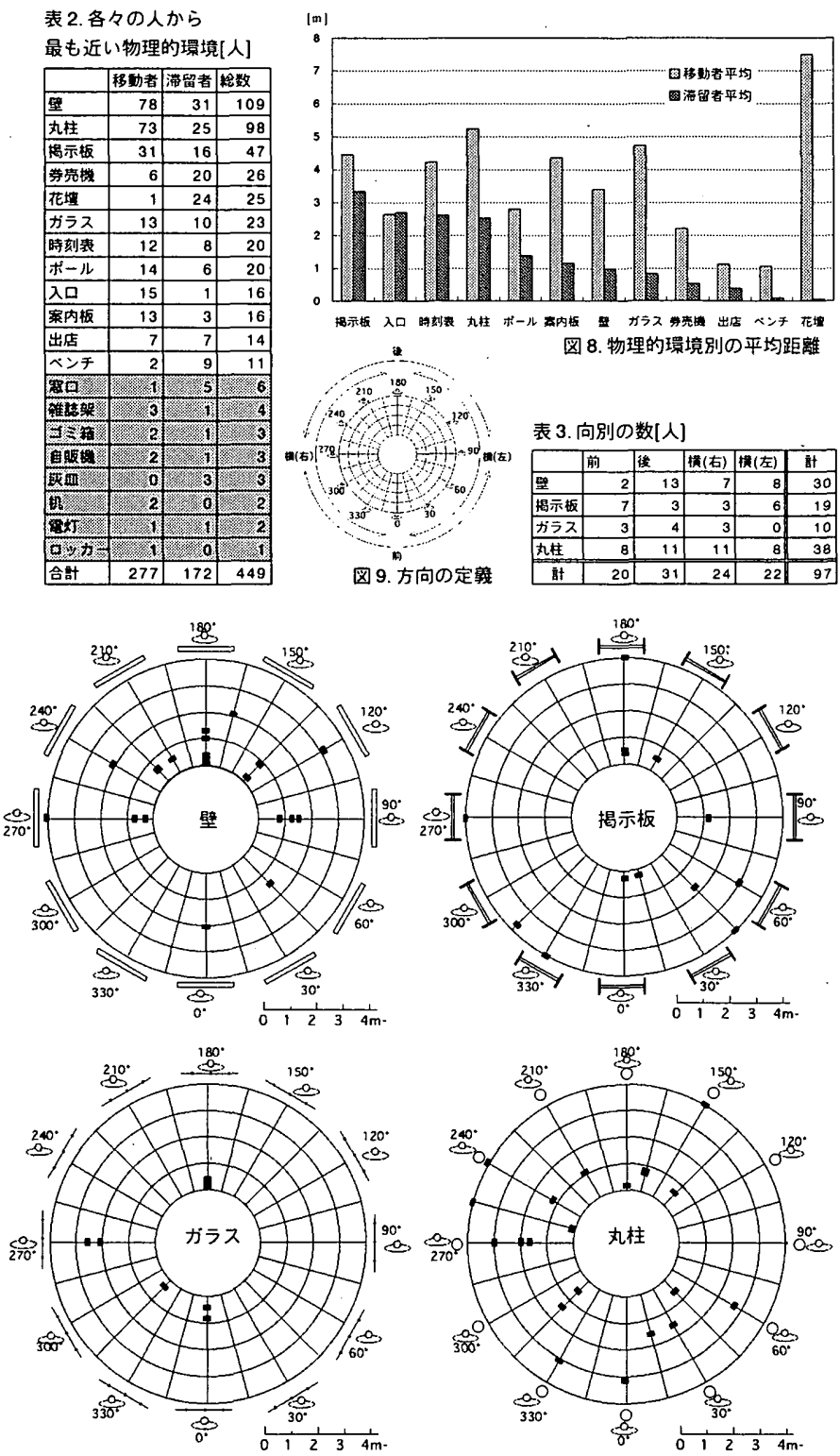

图 10.物理的環境に対する人の角度分布 
動をしているもの同士の方が小さい。この結果は群集の特性で得られ た同一行動同土が集まる傾向があることを支持し、実際の場において は同一行動をする他人に、より大きな影響を受けている場合が多いと 考えられる。

次に既往の実験による「すぐに離れたいと感じる領域」社8 と本稿の 異なる行動同土の結果を比べと、本稿の結果の方が大きくなってお り、実際の場面においては、人は他人とより距離をおいているという 結果であった。なお同一行動をしているもの同土の関係は、親しいも の同土が隣り合って歩いていたりしていることが多いために、ここで は除外している。

4-3. 図 14 は横軸に対象者から最も近い他人への距離、綎軸にその累 積の割合をとったものである。全ての場合において、大部分が近距離 に分布している。滞留者から移動者をみると、少数は離れて分布して いる。つまり、大部分の滞留者は、移動者の近くあるいは滞留者同士 近接しているか、、少数は大きく離れて孤立する。

4- 4. 移動者同士、滞留者同士の関係（図 15）は両者とも、左右 (90 ○、270 ) に多く、同一行動をしているもの同士は、横並びの位置 取りをすることが多い。さらに滞留者同士においては正面 $\left(0^{\circ}\right)$ も 多く、向かい合うまたは一方が背中を向ける位置関係を持つことも多 い。

\section{5. 速度変化からみる人と人の関係}

5-1.これまでパーソナルスペースは、実験的に対象者が不快かどうか という刺激值を元に求められてきたが、前章の結果が示すように実際 の場においては、既往の研究の結果よりも他人が進入してこない領域 は広い。そこで歩行時パーソナルスペースの限界値に他人が来たと き、人はその速度を変化させるのではないかという仮説から、移動者 同士の距離をVTRで計測した。くコンコース〉(図1のA、図16)に おいて、人の動きをビテオ撮影により収録し、1秒ごとの位置をプ ロットすることで、向きと速度社、、速度変化の様子を把握し、最も近 い他者の位置と角度を捉える。

5-2. ある時点の速度 (初速) と 1 秒後の速度 (終速) の関係は、図 17 のようになり、次の 4 つの場合に分けて分析する。A：初速が平均速 度よりも速く、かつ終速が初速よりも速くなった人、 $\mathrm{B}:$ 初速が平均 速度よりも遅く、かつ終速が初速よりも遅くなった人、C : 初速が平 匀速度よりも速く、終速が初速よりも遅くなった人、D:初速が平均 速度よりも遅く、終速が初速よりも速くなった人である。また、ある 人にとって他者がどの方向を向いているのかによって、正面、背面、 横（右、左）の4タイプに分け（図18）、本稿では相手の背面に位置 している時の対人距離菲10（図1）をみた。その結果、C及びDの値は ほぼ等しく、また Aと Bの值の間にある。種々の速度を定常状態とし て求めている既往研究整11.13 の結果と類似するものであるが、仮に拙 稿のテータが、速度が変化するという実際の場面で求めた移動時の パーソナルスペースの大きさと考えるならば、その大きさは前章で示 した他人か入ってこない領域よりもさらに大きい。

\section{6. 結論}

以上の分析結果をまとめると次のようになる。 1.群集としての特性 : 密度が低い空間では移動者、帯留者が行動する 領域は離れるが、空間の密度が高くなるにつれてその領域は近つき境
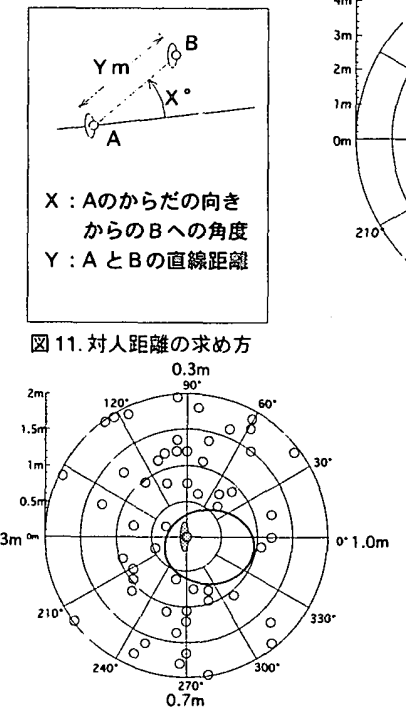

移動者から見た带留者との詨入距雜(移一港)

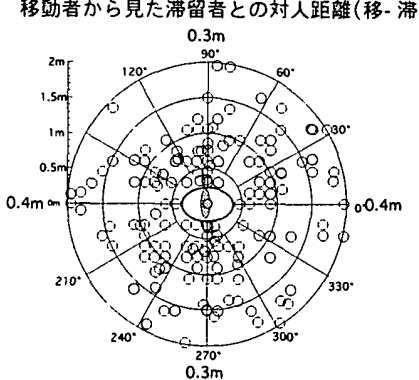

移動者から見た移動者との対人距離（移一移）
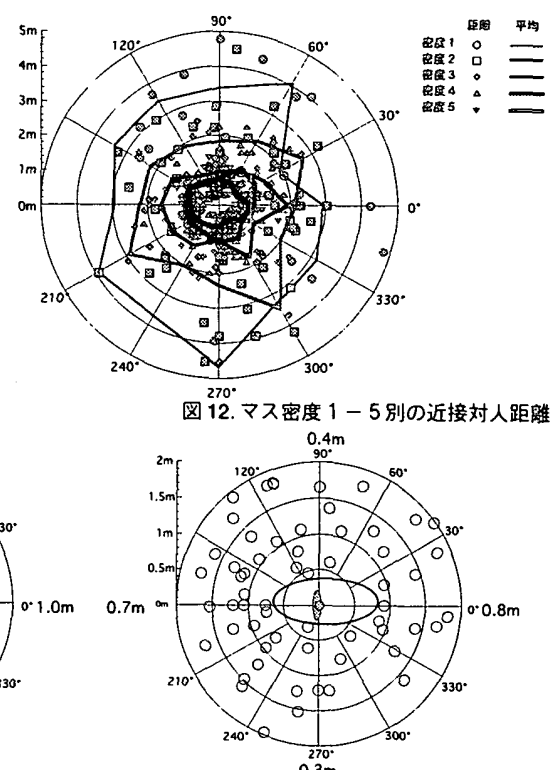

滞留者から見た移動者との対人距䧸（滞一移）

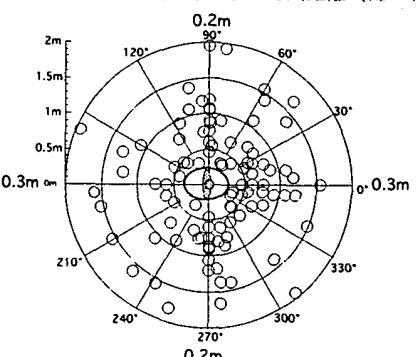

滞留者から見た滞留者との対人距離（涠－滞） 图 13. 对人距離の分布
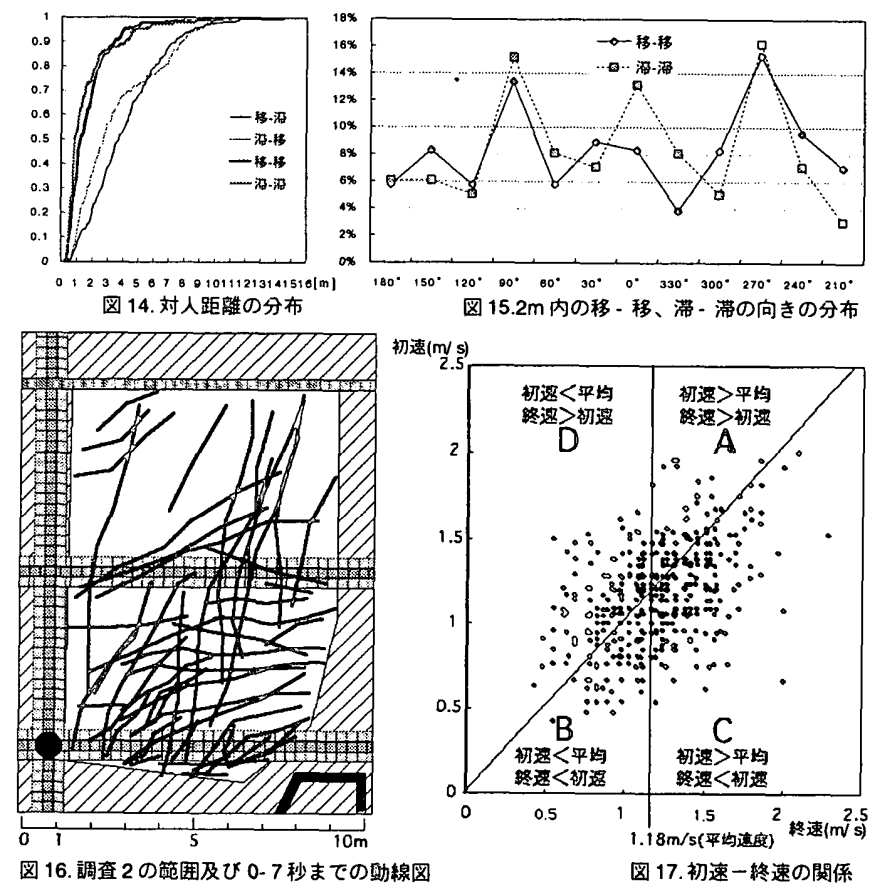

図 16. 調冝 2 の筫囲及び0-7秒までの助線図

図 17. 初速一耛速の関係

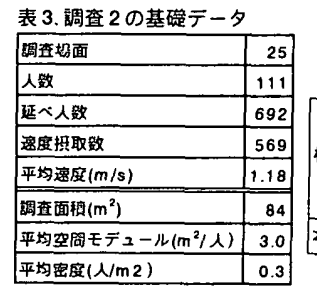

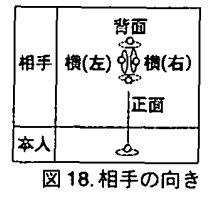

表 4. 相手の向き別粭数

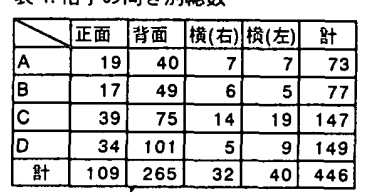


界が曖昧になり、それにつれて滞留者は減少する傾向がある。 2. 人とものとの関係 : 移動者が平均 $4.0 \mathrm{~m}$ と離れているのに対して、 滞留者は $1.2 \mathrm{~m}$ であり、ものとの関係が強くなる。個々に見ていくと、 視界が通らない壁などには向きあわず、揭示板などの安定性がないも のに対しては、壁などと比へてより離れた位置にいる傾向がある。ま た丸柱の場合には多様な位置取りをするなと、ものの性質によって環 境行動は影響を受ける。

3.人と人の関係: 同一行動をする他人に、より大きな影響を受けてい る場合が多いが、異なる行動をしているものも近距離に分布してい る。また少数の滞留者は離れて孤立するという場合もあるが、大部分 は移動者の近くあるいは滞留者のみで近接している。

4.人間の領域: 他人が入ってこない領域は、移動者あるいは滞留者と もに大きさは異なるが、既往の実験によるパーソナルスペースと同様 に、前後が左右に対して大きい形になっている。異なる行動をしてい るもの同士の大きさは、既往の実験による結果より大きい。さらに既 往実験で評価の尺度とされている不快であるか否かといった臨界点 を、拙稿では、速度変化という現象と仮定したが、ここで収録した結 果は、いわば移動時のパーソナルスペースの大きさと近似するものと 考えている。そしてこの結果は、4章で分析した「他人が入ってこな い領域」よりさらに大きいものであった。

おわりに

パーソナルスペースは、これまで実験により滞留者に対して意識的 に他者を近づけることで求められてきた。推論の域を出るものではな く、今後の検討に委ねるべき課題であるが、既往研究での結果と、本 稿での仮定に基づく結果との差異から次のことが考えられる。1）実 験では不快か否かを問う計測方法のために領域の閾值が小さく出てい るのではないか、2）滞留／移動という行動の違いに伴いパーソナル スペースは伸縮するのではないか、またこの場合に移動時は滞留時よ りもパーソナルスペースは大きくなるのではないか、というものであ る。

以上のように、人一環境の関係についてみてきたが、実在の場にお ける人の環境行動は、ものとの関係や移動/滞留という状況の違いに より、多様な相互関係があることわかった。環境行動における研究が 実験というある限られた人一環境の関係を見た結果と比較して、異な るものであった。しかし、あくまで本稿は速度変化のおこる時点を パーソナルスペースの閾值としていることから今後、更に多様な場面 を収録することで、より充実した説明が可能になると考える。

\section{参考文献)}

1. Hall,Edward T.著、日高敏隆・佐藤敏行訳:かくれた次元 みすず書房 1970

2. Sommer,Robert 著、稳山貞登訳：人間の空間 デザインの行動的研究 鹿 島研究所出版会 1972

3. J.J.Fru in 著、長島正充訳:歩行者の空間 理論とデサイン 鹿島研究所出版 会 1974

4. 中裕一郎 : 交差流動の構造一鉄道駅における旅客の交錯流動に関する研究 （1）一日本建築学会論文報告集 第 258 号 $\quad$ p.93-102 1977 年 8 月

5. 建部謙治, 中島一: 静止した障害物に対する単独步行者の回避行動 日本建 築学会 論文報告集 第 418 号 p.51-57 1990 年 12 月

6. 中村寛史:個体差も含めた歩行シュミレーションに関する研究 土木学会年 次学術講演会概要集 共通セッション p504-505 2001 年

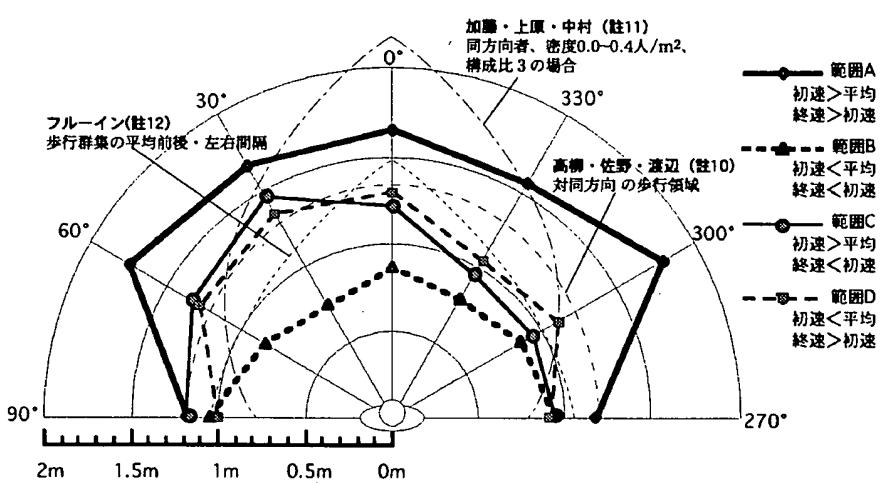

図 19. 相手の向き（背面）の速度変化別の平均対人距離

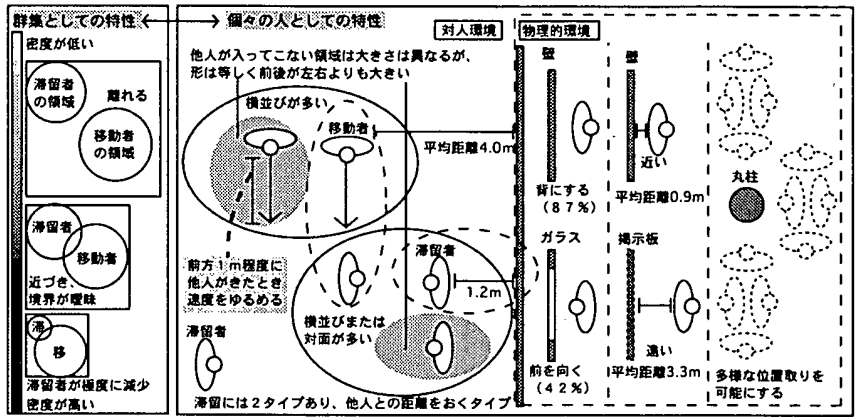

図 20. 実場面での滞留と移動の環境行動

註)

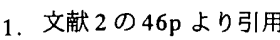

2. 高橋鹤志、西出和彦、高橋公子、他 : 空間における人間集合の研究ーその 1 、 $2 、 3$ (1980 年9月)、その $4 、 5$ (1981 年9月)、その6、7 (1982 年10月)、 その8（1983 年9月)、その9（1985 年 10 月）日本建築学会大会学術講演 梗概集

3. 例えば、人自身を含めて柱や揭示板などは、既往研究などでは単に移動の妨 げになる環境要素として扱われているか、、実際には、これらがむしろ人を惹 き付ける、あるいは「留まる」というようなアフォーダンスを有していると 考えられ、拙稿では、こうした要素と人間行動との関係が種々の様相を示す 点に研究の視点をおいている。

4. 文献 3 より、調查 2 における群集密度は、JJ.フルーインが定義するサービ ス基準で考えると、水準 $\mathrm{A}$ の歩 行者は、遅い人を追い抜いたり好きな歩行 速度を自由に選択できるだけの十分な面積がある密度から、水準Cの歩行者 が各自の歩行速度を選択したり、追い抜いたりする自由度は制限される密度 までであり、適当な込み合いと考えた。

5.この判別については、足が前後に開いていれば移動者、横に開いていれば帯 留者とし、写真のぶれも考虑した。また判断に迷うものは不明者としたの でほほ誤差はないと考えられる。

6. 歩行者空間モデュールは 1 人当たりが占める面積であり、群集密度ではわか りやすいため通常この形式が用いられる。単位は $\mathrm{m}^{2} /$ 人。

7. 通路はフルーインのサービス水準 $\mathrm{B}$ の行動に多少制限を受ける、広場とコン コースはサービス水準 $\mathrm{A}$ に当てはまる。

8. すぐに離れたいと感じる領域 前 $0.5 \mathrm{~m}$ 後ろ $0.3 \mathrm{~m}$ 横 $0.4 \mathrm{~m}$ 日本建筑 学会編 コンパクト資料集成〈住居〉 丸善 $1991 \mathrm{p} 135$

9. ある時点の向きと速度は、1 秒後の位置との関係から求めた。

10. 横向きの対人距離については、本調查ではデータが少ないため（表 4) 省略 した。また、正面については（図 19）形、大きさが特定できなかった。

11. 加藤邦夫、上原孝雄、中村和男、吉岡松太郎 : 群衆対向流動の解析 日本建 筑学会論文報告集 第 289 号 p.121 図2.31980 年3月

12. J.J.Fru in 著、長島正充訳:歩行者の空間 理論とデザイン 鹿島研究所出版 会 1974 p.35 図3-4

13. 高柳英明、佐野友紀、渡辺仁史：群衆交差流動における歩行領域確保に関す る研究 一歩行領域モテルを用いた解析一 日本建築学会計画系論文集 第 549 号 p.188-1894.2 2001 年11月 